\title{
Vitamin D supplementation improves SIRT1, Irisin, and glucose indices in overweight or obese type 2 diabetic patients: a double- blind randomized placebo-controlled clinical trial
}

Peivasteh Safarpour ${ }^{1}$, Milad Daneshi-Maskooni ${ }^{2}$, Mohammadreza Vafa ${ }^{1 *}$, Mitra Nourbakhsh ${ }^{3}$, Leila Janani ${ }^{4}$, Mohsen Maddah ${ }^{5}$, Fatemeh-Sadat Amiri ${ }^{1}$, Fereshteh Mohammadi ${ }^{5}$ and Homa Sadeghi ${ }^{6}$

\begin{abstract}
Background: Vitamin D (VD) may increase sirtuin 1 (SIRT1) and subsequently PPAR- $\gamma$ coactivator 1a (PGC-1a) and irisin levels and these improvements may reduce insulin resistance (IR). The aim was to assess the effects of vitamin D supplementation on SIRT1, irisin, and IR in overweight/obese type 2 diabetes (T2D) patients.

Methods: Ninety T2D males and females were recruited as a clinical trial study (mean of age and body mass index (BMI) of intervention and placebo groups were $50.05 \pm 10.17$ and $50.36 \pm 10.2 \mathrm{yrs}$. and $31.37 \pm 3.4$ and $30.43 \pm$ $3.2 \mathrm{~kg} / \mathrm{m}^{2}$, respectively). The inclusion criteria were T2D, VD deficient, BMl $>25 \mathrm{~kg} / \mathrm{m}^{2}$, and serum $\mathrm{HbA} 1 \mathrm{c}<8.5 \%$. The exclusion criteria were using vitamin and mineral supplements, having any acute disease, recent modifying dose or type of drugs. The supplementation was 50,000 IU/week VD or placebo for 8 weeks. The demographic characteristics, anthropometrics, dietary intakes and physical activity status, sun exposure status, fasting blood sugar (FBS) and insulin, glycosylated hemoglobin (HbA1C), irisin, SIRT1, 25-hydroxy D3 $(25(\mathrm{OH}) \mathrm{VD})$, homeostasis model assessment of insulin resistance (HOMA-IR), and quantitative insulin sensitivity check index (QUICKI) were determined. The significant $P$-value was $\leq 0.05$.

Results: The increase of serum VD, SIRT1, and irisin in the intervention group was significant $(p<0.001)$. $\mathrm{HbA1c}$ was decreased significantly by $1 \%$. The changes in the other glucose indices (FBS, insulin, and IR) were non-significant.
\end{abstract}

Conclusions: VD supplementation may improve T2D by decreasing HbA1C and increasing SIRT1 and irisin in VD deficient T2D patients. Further trials are suggested.

Trial registration: Iranian Registry of Clinical Trials, IRCT201604202365N11. Registered 21/08/2016, http://en.irct. ir/trial/2019.

Keywords: Vitamin D, SIRT1, Irisin, Glucose indices, type 2 diabetes, Overweight/obesity

\footnotetext{
* Correspondence: rezavafa@yahoo.com

'Department of Nutrition, School of Public Health, Iran University of Medical

Sciences, Tehran, Iran

Full list of author information is available at the end of the article
}

(c) The Author(s). 2020 Open Access This article is distributed under the terms of the Creative Commons Attribution 4.0 International License (http://creativecommons.org/licenses/by/4.0/), which permits unrestricted use, distribution, and reproduction in any medium, provided you give appropriate credit to the original author(s) and the source, provide a link to the Creative Commons license, and indicate if changes were made. The Creative Commons Public Domain Dedication waiver (http://creativecommons.org/publicdomain/zero/1.0/) applies to the data made available in this article, unless otherwise stated. 


\section{Background}

Diabetes mellitus is a metabolic disease characterized by hyperglycemia resulting from defects in insulin secretion or action or both [1]. Obesity is an important risk factor increases cellular oxidative stress, insulin resistance (IR), and pancreatic beta cells malfunction [2]. In addition, vitamin D (VD) deficiency is highly prevalent in many societies and ages. According to Iranian Multi-Centric Osteoporosis Study (IMOS), 2009, 72.1\% of men and $75.1 \%$ of women had mild to severe VD deficiency. Globally, about $50 \%$ of the population are VD deficient. It is estimated that about 1 billion people all over the world are affected by different degrees of vitamin D deficiency [3-6].

According to recent studies, IR as the most important cause of T2D was inversely related to VD [6-8]. Moreover, serum 25-OH VD is significantly lower among diabetic patients compared with non-diabetic ones $[9,10]$. Also, the relationship between serum 25-OH VD and insulin secretion was significant according to some studies [11].

The hyperglycemia, hyperlipidemia, and inflammatory cytokines in diabetes can likely increase oxidative stress and decrease silent mating type information regulation 2 homolog 1 (sirtuin 1 [SIRT1]) levels [12].

Sirtuins as class III histone deacetylases are categorized into 7 types among which, SIRT1 has been studied more than other categories in humans. SIRT1 may play a role in chronic diseases such as diabetes. It affects glucose metabolism in the liver, pancreas, muscle and adipose tissue. The expression and activity of SIRT1 are reduced in hunger, calorie restriction, and some chronic diseases such as diabetes. Accordingly, SIRT1 activation may improve glucose indices and mitochondria function [13-16].

In addition, VD may increase human endothelial SIRT1 level and activity that can be downregulated by Hydrogen Peroxide. Anti-cancer effects of VD are related to VD receptor (VDR) and Forkhead box O (FOXO) protein interaction, phosphorylation stimulation, and SIRT1. The insulin-sensitizing effect of VD is likely in relation to SIRT1 [17].

Irisin is a myokine regulates energy metabolism in exercise and improves insulin resistance [18]. It is secreted in response to Peroxisome Proliferator-Activated Receptor (PPAR)- $\gamma$ Coactivator (PGC-1 $\alpha$ ), and low irisin levels may decrease expression and activation of PGC-1 $\alpha$. Also, T2D patients have low serum levels of irisin and PGC-1 $\alpha$ [19-22].

According to the separate studies, VD may increase SIRT1, and subsequently PGC-1 $\alpha$ and Irisin. These changes can improve insulin resistance. Thus, VD may decrease insulin resistance by increasing SIRT1 and Irisin (Fig. 1). So, this trial was planned to assess the effects of vitamin D on serum glucose, SIRT1, and Irisin levels in overweight/obese T2D patients.

\section{Methods}

\section{Study design}

This double-blinded randomized clinical trial was conducted on 90 obese T2D patients at Shahid Beheshti Diabetes Clinic, Bandar-E-Anzali, Gilan, Iran. The study lasted from the beginning of autumn 2016 to the end of autumn 2016.

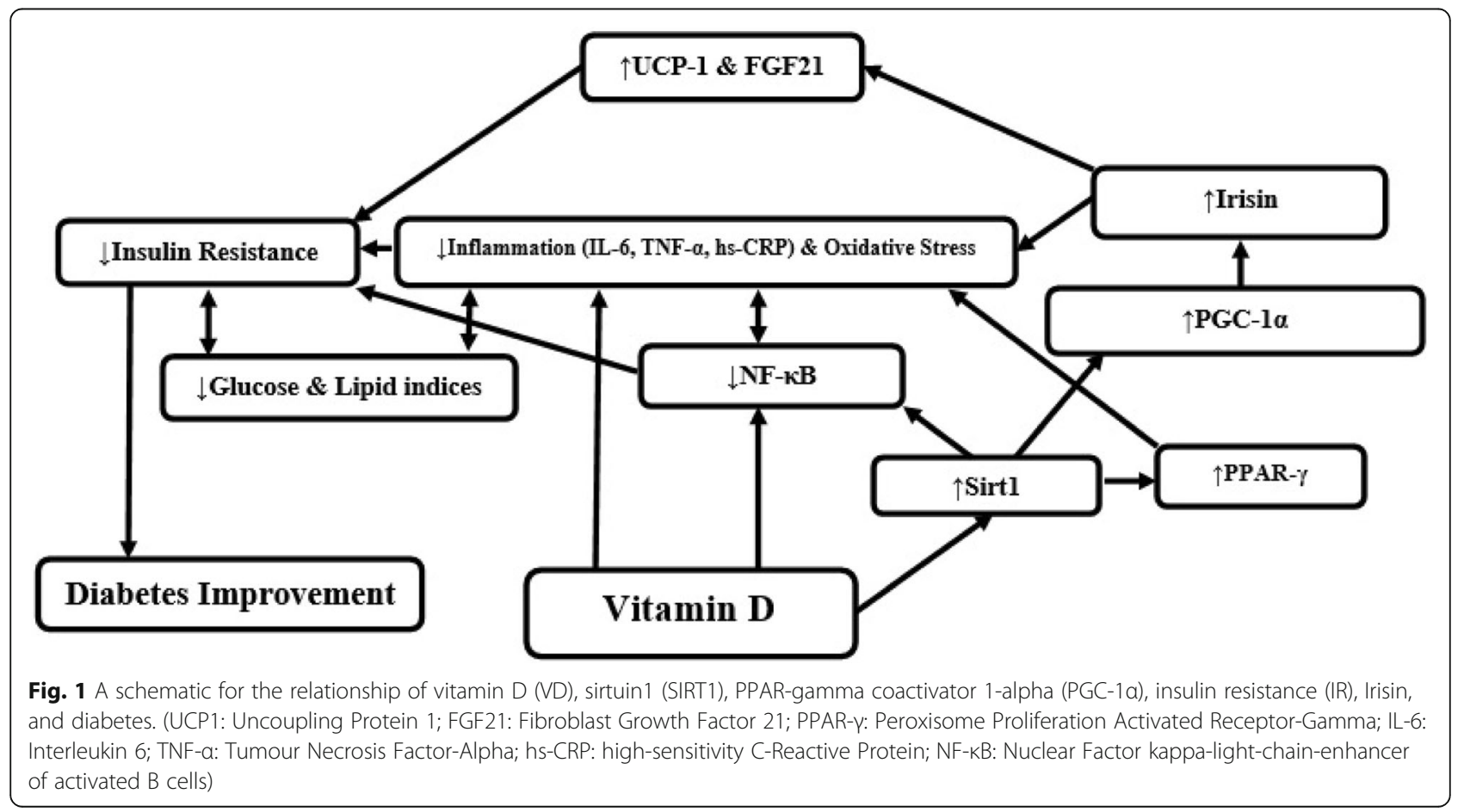


The participants signed a "written informed consent form" at the beginning. Ninety patients were randomly divided into placebo or intervention groups with a 1:1 ratio. The intervention group took 8 VD pearls $(50,000$ IU/week, Zahravi $\mathrm{Co}^{\oplus}$ ), and the placebo group took similar pearls containing oral paraffin without VD $(50,000$ IU/week, Zahravi $\mathrm{Co}^{\circledR}$ ). The duration of the intervention was 8 weeks. During the intervention, the compliance status including follow-up, side effects, and complications was weekly checked by calling. At the end, the number of the used pearls, returned blisters, and packs were recorded.

Inclusion criteria were 25-65 years old, having $\mathrm{T} 2 \mathrm{D}$, serum $\mathrm{HbA} 1 \mathrm{c}<8.5 \%, 25 \mathrm{~kg} / \mathrm{m} 2 \leq \mathrm{BMI}$, and the written informed consent form. Exclusion criteria were the inability to cooperating, acute diseases influencing the intervention, intake of the antioxidant and multivitamin-mineral supplements during the past 3months so far, changing the type and dose of T2D medications, and taking less than about $90 \%$ of the study's supplements.

The outcomes were serum 25-OH VD, SIRT1, Irisin, HbA1c, IR indexes, FBS, and serum insulin.

\section{Measures}

At the beginning and end, the demographic characteristics, anthropometrics, and dietary intakes by two 24$\mathrm{h}$ food recall (a weekend and a working day) were determined. Physical activity was measured by a short form of the international physical activity questionnaire (IPAQ) [23]. The sun exposure status was assessed using a valid questionnaire [24]. At the beginning and end, the blood taking from the brachial vein for measuring the serum factors was done. Serum glucose was measured by the Olympus ${ }^{\oplus}$ device and Delta ${ }^{\oplus}$ kits.

The glycosylated hemoglobin was determined using Nycocard ${ }^{\circ}$ kits in Nyco Card Reader ${ }^{\circ}$ (Made in Norway). Insulin was measured by the Cobas e $411^{\circ}$ device and Roche ${ }^{\bullet}$ kit. Irisin was measured by Zellbio GmbH kit Cat.No: ZB-13253 J-H9648 (Germany) ${ }^{\circledR}$, with a normal range of $2-80 \mathrm{ng} / \mathrm{ml}$ and sensitivity of 0.1 ng/ml. SIRT1 was measured by Zellbio $\mathrm{GmbH}$ kit Cat.No: ZB-12557J-H9648(Germany) ${ }^{\circ}$, with a normal range of $5-160 \mathrm{ng} / \mathrm{ml}$ and sensitivity of $1 \mathrm{ng} / \mathrm{ml}$. ELISA method; ELISA reader (Model: Tecan A-5082 Made in Austria ${ }^{\oplus}$.

$25-\mathrm{OH}$ VD was measured by $25-(\mathrm{OH}) \mathrm{D}_{3}$ quantitative diagnostic kit (Immuno Diagnostic Systems (IDS), $U K)^{\circledR}$, which is an Enzyme Immunoassay kit with a sensitivity of $5 \mathrm{nmol} / \mathrm{L}$. The ELISA method and ELISA reader (Model: Tecan A-5082 Made in Austria ${ }^{\oplus}$ ) were used for Irisin, SIRT1, and 25-OH D3. The insulin resistance was determined by HOMA-IR and QUICKI indexes $[25,26]$ as the following formula:

$$
\begin{aligned}
& \text { Insulin resistance }=[\text { fasting glucose }(\mathrm{mmol} / \mathrm{L}) \\
& \times \text { fasting insulin }(\mu I U / m l)] / 22.5 \\
& \text { Insulin Sensitivity }=1 \div[\log \text { fasting glucose }(\mathrm{mmol} / \mathrm{l}) \\
& +\log \text { fasting insulin }(\mu I U / m l)]
\end{aligned}
$$

\section{Statistical analysis}

According to the Baziar et al study with 1.33 mean difference of HOMA-IR, 1.18 standard deviation for vitamin D group, and 2.84 standard deviations for placebo group [27], the sample size was calculated 45 peoples in any groups using G-Power software and considering $\alpha=$ $5 \%, \beta=20 \%$, and dropout percentage $=12.5 \%$.

Randomization was done using 23 quadratic blocks and www.sealedenvelope.com. The blinding was according to unique codes produced by software for each subject. Non-parametric, t-test, Mann-Whitney, Chi-square, and ANCOVA tests and SPSS $_{16}$ statistical software were used for the analyses. The final analysis model was adjusted for the baseline values as potential confounders. $P$-value $<0.05$ was statistically considered significant. The dietary intakes were analyzed by the Nutritionist $($ IV) software. The modified intention-to-treat (m-ITT) method [28] was used for the missing data (3 participants in the intervention group and 2 ones in the placebo group) (Fig. 2).

This clinical trial was approved by the ethics committee of Iran University of Medical Sciences (IUMS) (Code: IR.IUMS.REC.1395.9223475201), and Iranian Registry of Clinical Trials (IRCT) (Registration No: IRCT2016042023 65N11). An informed consent form (in Persian) obtained from all the participants. Participation was free, and a participant could withdraw at whatever point the person feels he/she was unable to continue. The dose of VD was for insufficient VD status that side-effects had not been reported previously [29]. All of the ethical codes were according to the Helsinki agreement [30]. The personal information of participants was kept secret before, during, and after the trial. After measurements, at the end, a VD supplement was given to the placebo group according to the protocol.

\section{Results}

According to the flow diagram of participants, a total of 176 T2D patients referred to the diabetes clinic were screened (informed consent, medical history, questionnaire), of whom 86 patients did not meet the eligibility criteria. Ninety participants were randomized that 5 patients did not complete the study (for personal reasons; VD group $n=3$; placebo $n=2$ ). Thus 85 participants completed the 


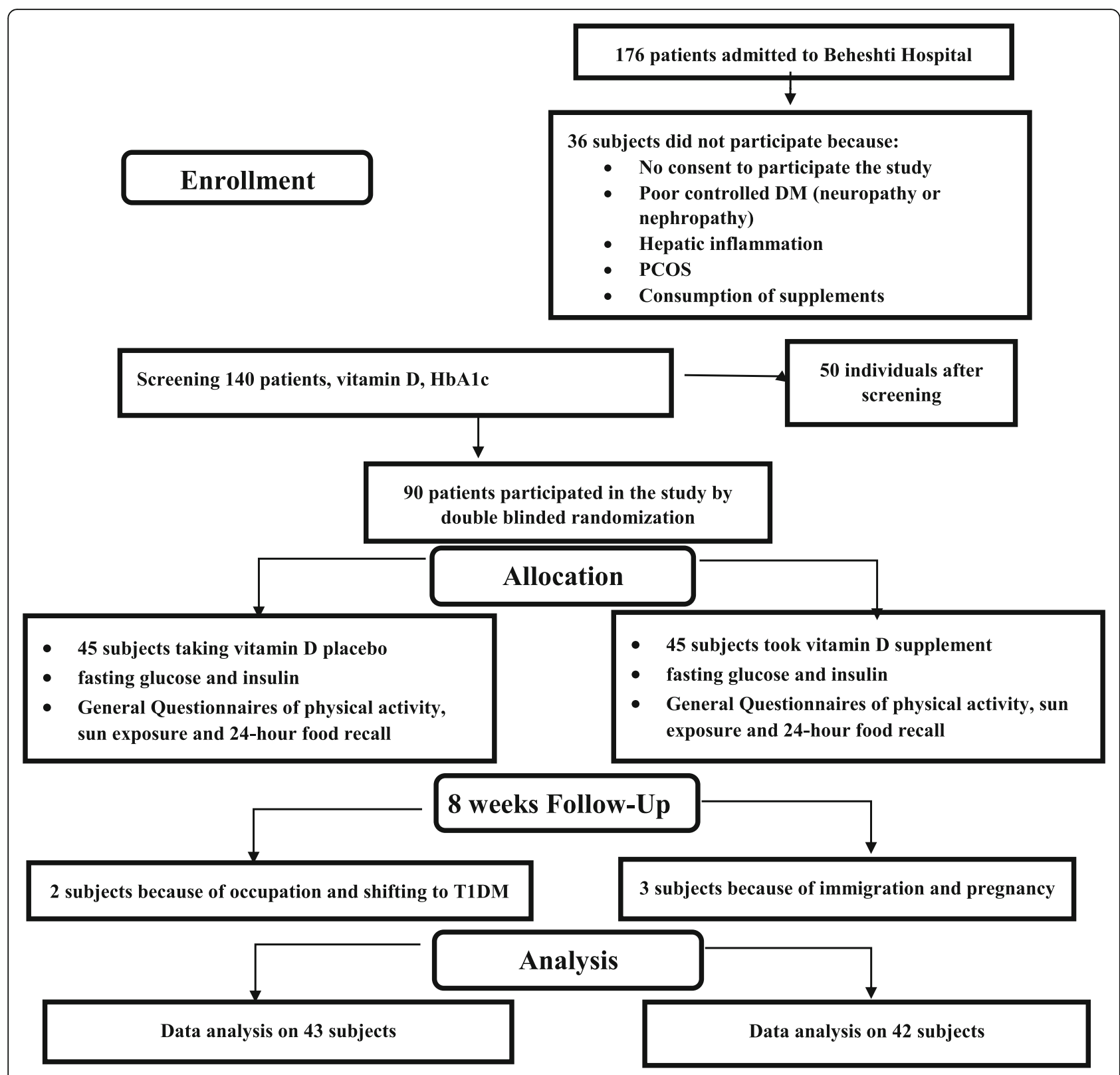

Fig. 2 Flow diagram of participants with type 2 diabetes and overweight/obesity grade 1

trial (VD group $n=42$; placebo $n=43$ ) and the data of them were analyzed (Fig. 2).

Most of the participants were women with type 1 obesity $\left(30 \leq \mathrm{BMI}<35\right.$ [BMI $=34.25 \mathrm{~kg} / \mathrm{m}^{2}$, weight: 59 $115 \mathrm{~kg}$, height: $163-184.5 \mathrm{~cm}])$, the mean age of 50 years (25-65 year), recent diagnosed T2D nearly less than 6 years, and consumption of maximum 2 types of antihyperglycemic medications. The baseline characteristics including age, gender, weight, height, BMI, duration of diabetes, type and dose of medications, and employment status were similar between two groups before intervention (Table 1).
Physical activity status (MET-min/week) was not significantly different between the two groups. Within the placebo group, weight and BMI decreased significantly $(P<0.05)$. However, these differences were not significant between the two groups $(P>0.05)$ (Table 2$)$.

Energy, macronutrients, micronutrients, and antioxidant intakes were not significantly different within and between groups (Tables 3 and 4). Within the VD group, zinc intake increased significantly $(\mathrm{P}<0.05)$, but within the placebo group, zinc intake decreased significantly $(\mathrm{P}<0.05)$. However, this difference was not significant between the two groups $(\mathrm{P}>0.05$, Table 4$)$. 
Table 1 The mean and standard deviation of the baseline characteristics of type 2 diabetes patients

\begin{tabular}{|c|c|c|c|c|}
\hline \multirow[t]{2}{*}{ Variable } & \multirow[t]{2}{*}{ Category } & \multicolumn{2}{|l|}{ Group } & \multirow[t]{2}{*}{$P$-value } \\
\hline & & $\begin{array}{l}\text { Vitamin D } \\
(N=42)\end{array}$ & $\begin{array}{l}\text { Placebo } \\
(N=43)\end{array}$ & \\
\hline Age $(Y)$ & - & $50.36(10.2)$ & $50.05(10.7)$ & $0.892^{*}$ \\
\hline Weight (kg) & - & $77.38(10.9)$ & $79.27(11.6)$ & $0.442^{*}$ \\
\hline Height (cm) & - & $159.35(8.0)$ & $158.77(7.6)$ & $0.736^{*}$ \\
\hline $\mathrm{BMI}\left(\mathrm{kg} / \mathrm{m}^{2)}\right)$ & - & $30.43(3.2)$ & $31.37(3.4)$ & $0.194^{*}$ \\
\hline Disease duration (months) & - & $65.52(38.5)$ & $67.02(35.4)$ & $0.664^{*}$ \\
\hline \multirow[t]{2}{*}{ Medications (per day) } & Metformin $(500$ mg/d) & $2.11(1.13)$ & $2.51(1.26)$ & \multirow[t]{2}{*}{$0.135^{*}$} \\
\hline & Glibenclamide (5 mg/d) & $1.31(0.94)$ & $0.95(0.78)$ & \\
\hline \multirow[t]{2}{*}{ Gender } & Male & $7.00(16.7)$ & $8.00(18.6)$ & \multirow[t]{2}{*}{$0.815^{* *}$} \\
\hline & Female & $35.00(83.3)$ & $35.00(81.4)$ & \\
\hline \multirow[t]{2}{*}{ Employment status } & Unemployed & $32.00(76.2)$ & $32.00(74.4)$ & \multirow[t]{2}{*}{$0.850^{* *}$} \\
\hline & employed & $10.00(23.8)$ & $11.00(25.6)$ & \\
\hline
\end{tabular}

*Independent t-test; **Chi-square test, $Y$ Year, $\mathrm{kg}$ Kilogram, $\mathrm{cm}$ Centimeter, BMI Body mass index, mg Milligram

According to the final analysis model, the differences of serum VD, SIRT1, Irisin, and HbA1c were significant within and between groups $(\mathrm{P}<0.05)$. Serum VD level was doubled compared to the baseline level, and HbA1c decreased by $1 \%$ among the VD group (Table 5 ). Within the VD group, irisin and SIRT1 increased significantly $(\mathrm{P}<0.05)$. The differences in fasting glucose and insulin, HOMA-IR, and QUICKI were not significant between the two groups (Table 6). The sun-exposure status was not significantly different within and between groups.

\section{Safety}

The patients reported no side effects associated with treatment.

\section{Discussion}

Vitamin D supplementation (50,000 IU/week) for 8 weeks increased serum VD levels in T2D patients with VD deficiency. Compared to placebo, VD increased SIRT1 and Irisin and decreased $\mathrm{HbA1c}$ by $1 \%$ significantly. The differences in fasting insulin and glucose, HOMA-IR, and QUICKI were not significant. Within the placebo group, serum VD levels decreased significantly.

The results of some studies of the effects of VD supplementation on diabetes showed controversy that the following is referred to some of them.

In some studies, VD effects on insulin and glucose levels of diabetic patients were similar to our trial [31-36].

In line with our results, Polidoro et al, 2013 reported that SIRT1 and Irisin levels increased in the VD group and decreased in the placebo group significantly [17]. The decreases can likely be attributed to progressing VD deficiency in the placebo group after 2 months.

In Anastasilakis et al, 2013 study, irisin levels after osteoporotic fractures in postmenopausal women with low bone mineral density for 3 months didn't show a significant correlation with serum 25(OH)VD levels. The decrease of Irisin was related to physical inactivity and a sedentary lifestyle during fracture [37]. In another study on healthy peoples, a one-time injection of 100,000 IU

Table 2 The mean and standard deviation of physical activity, weight, and BMI in type 2 diabetes patients

\begin{tabular}{|c|c|c|c|c|}
\hline Variable & & $\begin{array}{l}\text { Vitamin D } \\
(N=42)\end{array}$ & $\begin{array}{l}\text { Placebo } \\
(N=43)\end{array}$ & $P$-value \\
\hline \multirow[t]{3}{*}{ Physical activity (MET. Minutes/week) } & Baseline & $685.50(99-34,755)$ & $462.00(99-28,560)$ & 0.346 \\
\hline & After intervention & $693.00(99-33,831)$ & $462.00(99-28,659)$ & 0.333 \\
\hline & $P$-value ${ }^{* *}$ & 0.104 & 0.811 & \\
\hline \multirow[t]{3}{*}{ Weight (kg) } & Baseline & $77.38(10.92)$ & $79.27(11.67)$ & 0.442 \\
\hline & After intervention & $77.13(10.81)$ & $78.77(11.53)$ & 0.502 \\
\hline & $P$-value ${ }^{* *}$ & 0.076 & 0.011 & \\
\hline \multirow[t]{3}{*}{$\mathrm{BMI}\left(\mathrm{kg} / \mathrm{m}^{2}\right)$} & Baseline & $30.43(3.23)$ & $31.37(3.40)$ & 0.194 \\
\hline & After intervention & $30.34(3.32)$ & $31.18(3.42)$ & 0.254 \\
\hline & $P$-value ${ }^{* *}$ & 0.097 & 0.009 & \\
\hline
\end{tabular}

*Independent t-test, **Paired t-test, $\mathrm{kg}$ Kilogram, $\mathrm{cm}$ Centimeter, BMl Body mass index, mg Milligram, MET Metabolic equivalent 
Table 3 The mean and standard deviation of energy intake, macronutrients, and micronutrients before and after intervention in type 2 diabetes patients

\begin{tabular}{|c|c|c|c|c|}
\hline & & $\begin{array}{l}\text { Vitamin D } \\
(N=42)\end{array}$ & $\begin{array}{l}\text { Placebo } \\
(N=43)\end{array}$ & $P$-value ${ }^{*}$ \\
\hline \multirow[t]{3}{*}{ Energy (kcal/day) } & Baseline & 1638.59 (377.82) & 1578.38 (399.64) & 0.478 \\
\hline & After intervention & $1701.36(485.61)$ & $1564.68(392.75)$ & 0.157 \\
\hline & $P$-value ${ }^{* *}$ & 0.381 & 0.871 & \\
\hline \multirow[t]{3}{*}{ Protein (g/day) } & Baseline & $82.27(23.34)$ & 78.79 (31.82) & 0.568 \\
\hline & After intervention & $89.31(35.83)$ & $80.31(32.16)$ & 0.226 \\
\hline & $P$-value ${ }^{* *}$ & 0.190 & 0.823 & \\
\hline \multirow[t]{3}{*}{ Carbohydrate (g/day) } & Baseline & $232.69(67.62)$ & $220.85(54.71)$ & 0.377 \\
\hline & After intervention & $231.41(62.34)$ & $214.21(51.19)$ & 0.168 \\
\hline & $P$-value ${ }^{* *}$ & 0.891 & 0.522 & \\
\hline \multirow[t]{3}{*}{ Total fat (g/day) } & Baseline & $47.61(11.25)$ & $46.83(12.22)$ & 0.760 \\
\hline & After intervention & $51.31(17.33)$ & $47.41(14.13)$ & 0.258 \\
\hline & $P$-value ${ }^{* *}$ & 0.199 & 0.830 & \\
\hline \multirow[t]{3}{*}{ SFA (g/day) } & Baseline & $16.10(4.58)$ & $15.35(3.75)$ & 0.413 \\
\hline & After intervention & $16.01(6.10)$ & $15.74(4.54)$ & 0.819 \\
\hline & $P$-value ${ }^{* *}$ & 0.913 & 0.639 & \\
\hline \multirow[t]{3}{*}{ MUFA (g/day) } & Baseline & $16.06(3.85)$ & $15.59(5.07)$ & 0.636 \\
\hline & After intervention & $17.13(5.85)$ & $15.56(4.86)$ & 0.182 \\
\hline & $P$-value ${ }^{* *}$ & 0.265 & 0.976 & \\
\hline \multirow[t]{3}{*}{ PUFA (g/day) } & Baseline & $9.98(3.04)$ & $10.04(3.45)$ & 0.836 \\
\hline & After intervention & $10.49(2.47)$ & $9.97(3.86)$ & 0.480 \\
\hline & $P$-value ${ }^{* *}$ & 0.365 & 0.919 & \\
\hline \multirow[t]{3}{*}{ Calcium (mg/day) } & Baseline & 835.33 (279.75) & 838.41 (301.51) & 0.961 \\
\hline & After intervention & 804.44 (324.89) & 833.63 (292.95) & 0.665 \\
\hline & $P$-value & 0.487 & 0.929 & \\
\hline \multirow[t]{3}{*}{ Phosphorus (mg/day) } & Baseline & $1444.29(402.18)$ & $1364.80(372.84)$ & 0.347 \\
\hline & After intervention & $1459.15(467.88)$ & 1355.23 (388.99) & 0.268 \\
\hline & $P$-value & 0.814 & 0.897 & \\
\hline \multirow[t]{3}{*}{ Vitamin D ( $\mu \mathrm{g} /$ day) } & Baseline & $1.73(1.28)$ & $1.84(1.41)$ & 0.710 \\
\hline & After intervention & $1.58(1.18)$ & $1.64(1.22)$ & 0.835 \\
\hline & $P$-value ${ }^{* *}$ & 0.386 & 0.334 & \\
\hline \multirow[t]{3}{*}{ Total fiber (g/day) } & Baseline & $29.23(10.67)$ & $26.58(7.56)$ & 0.192 \\
\hline & After intervention & $29.96(8.25)$ & $25.91(9.05)$ & 0.578 \\
\hline & $P$-value ${ }^{* *}$ & 0.127 & 0.603 & \\
\hline
\end{tabular}

*Independent t-test, **Paired t-test, SFA Saturated fatty acid, MUFA Mono unsaturated fatty acid, PUFA Poly unsaturated fatty acid

VD increased serum 25(OH)VD levels and the changes of serum irisin were non-significant. Only in one subject out of 28, the serum irisin increased by three times; which may be related to genetic variations in response to the intervention [38].

A study in 2017 showed serum irisin levels were decreased after 2 weeks' mountain climbing. The possible reasons were exposure to hypoxia, the energy-related mechanisms, and the revitalization of musculoskeletal cells in response to hypoxia [39].
The changes in physical activity in our study were not significant. Accordingly, the improvement of serum irisin levels in the VD group was independent of physical activity levels. On the other hand, the decrease and increase of irisin can be related to serum VD levels or the dietary intake of VD in T2D patients.

According to the different studies, the effects of VD on glucose indices are controversial.

Similar to our study, two separate studies with 50,000 IU/d VD didn't find significant effects on FBS levels [33, 
Table 4 The mean and standard deviation of the dietary antioxidants before and after intervention in type 2 diabetes patients

\begin{tabular}{|c|c|c|c|c|c|c|}
\hline & & $\begin{array}{l}\text { Vitamin D } \\
(N=42)\end{array}$ & & $\begin{array}{l}\text { Placebo } \\
(N=43)\end{array}$ & & $P$-value \\
\hline \multirow[t]{3}{*}{ Beta-Carotene (micg/day) } & Baseline & 3780.76 & 3117.63 & 5440.75 & 6623.31 & 0.242 \\
\hline & After intervention & 4379.33 & 4073.18 & 4419.51 & 4235.22 & \\
\hline & $P$-value & 0.362 & & 0.963 & & \\
\hline \multirow[t]{3}{*}{ Vitamin A (micg/day) } & Baseline & 878.74 & 663.17 & 893.10 & 723.97 & 0.952 \\
\hline & After intervention & 757.20 & 433.10 & 781.86 & 489.78 & \\
\hline & $P$-value ${ }^{* *}$ & 0.059 & & 0.947 & & \\
\hline \multirow[t]{3}{*}{ Vitamin E (mg/day) } & Baseline & 15.79 & 4.15 & 15.96 & 4.63 & 0.951 \\
\hline & After intervention & 15.42 & 4.18 & 15.67 & 4.13 & \\
\hline & $P$-value ${ }^{* *}$ & 0.882 & & 0.522 & & \\
\hline \multirow[t]{3}{*}{ Vitamin C (mg/day) } & Baseline & 122.87 & 81.12 & 139.18 & 108.88 & 0.596 \\
\hline & After intervention & 120.19 & 74.06 & 123.56 & 76.57 & \\
\hline & $P$-value ${ }^{* *}$ & 0.101 & & 0.528 & & \\
\hline \multirow[t]{3}{*}{ Selenium (mg/day) } & Baseline & 238.09 & 54.43 & 235.76 & 88.75 & 0.386 \\
\hline & After intervention & 213.06 & 61.64 & 230.75 & 83.54 & \\
\hline & $P$-value & 0.696 & & 0.887 & & \\
\hline \multirow[t]{3}{*}{ Zinc (mg/day) } & Baseline & 20.61 & 5.82 & 20.46 & 5.85 & 0.306 \\
\hline & After intervention & 20.96 & 6.40 & 19.39 & 6.05 & \\
\hline & $P$-value & 0.003 & & 0.005 & & \\
\hline \multirow[t]{3}{*}{ Manganese (mg/day) } & Baseline & 12.57 & 3.61 & 12.83 & 5.54 & 0.381 \\
\hline & After intervention & 11.48 & 4.04 & 12.79 & 4.62 & \\
\hline & $P$-value ${ }^{* *}$ & 0.240 & & 0.052 & & \\
\hline \multirow[t]{3}{*}{ Copper (micg/day) } & Baseline & 2.79 & 0.75 & 2.67 & 1.05 & 0.268 \\
\hline & After intervention & 2.54 & 0.75 & 2.73 & 0.93 & \\
\hline & $P$-value & 0.364 & & 0.988 & & \\
\hline \multirow[t]{3}{*}{ Magnesium (mg/day) } & Baseline & 717.30 & 168.48 & 725.50 & 247.19 & 0.461 \\
\hline & After intervention & 680.08 & 191.00 & 732.94 & 224.49 & \\
\hline & $P$-value ${ }^{* *}$ & 0.695 & & 0.284 & & \\
\hline
\end{tabular}

*Independent t-test, **Paired t-test

34]. However, in two other studies, the increased serum VD levels were significantly related to FBS [40, 41]. The likely reasons may be the dietary patterns, timing or type of hyperglycemia medications, and the genetic differences of the populations.

In contrast, some studies of VD effects reported a significant improvement in fasting serum insulin [34, 42-44]. The potential mechanisms may be the presence of VD receptors (VDRs) in pancreas cells and expression of 1alpha-hydroxylase in them [37] and the existence of some elements on human insulin promotors that respond to VD and can activate insulin gene transcription [38-40].

In line with this trial, the different studies showed a significant decrease in HbA1c of diabetics' patients [33, $34,43,44]$. However, the effect of VD on HbA1c was non-significant in two separate studies $[45,46]$. The reasons may be the unadjusted potential confounders and the different design of these studies. The potential mechanisms are unknown.

No significant changes in insulin resistance and sensitivity of our trial were similar to Jorde et al, 2010 study [40], and SUNNY trial [34]. However, some studies reported a significant improvement in HOMA-IR or QUICKI with vitamin $\mathrm{D}[43,44,47]$. The reason may be changing fasting serum glucose and insulin levels after the intervention. Vitamin D may decrease blood glucose by increasing insulin sensitivity, glucose uptake of peripheral tissues, and glycogen synthesis in liver [14]. The existence of VDR and expression of 1- $\alpha$-hydroxylase in pancreatic cells may be a probable mechanism of the VD effect on insulin secretion [48]. Also, response elements to VD in human insulin promoters may activate insulin gene transcription $[15,16]$.

The lower serum 25(OH)-VD level is associated with abdominal and peripheral obesity, physical inactivity, 
Table 5 The mean and standard deviation of the primary variable before and after intervention in type 2 diabetes patients

\begin{tabular}{|c|c|c|c|c|c|}
\hline & & $\begin{array}{l}\text { Vitamin D } \\
(N=42)\end{array}$ & $\begin{array}{l}\text { Placebo } \\
(N=43)\end{array}$ & crude $P$-value & Adjusted $P$-value \\
\hline \multirow[t]{3}{*}{ VitaminD (ng/ml) } & Baseline & $17.24(7.83)$ & $17.56(7.82)$ & 0.853 & $<0.001$ \\
\hline & After intervention & $38.86(10.76)$ & $14.79(7.08)$ & $<0.001$ & \\
\hline & $P$-value & $<0.001$ & $<0.001$ & & \\
\hline \multirow[t]{3}{*}{ HbA1c (\%) } & Baseline & $7.51(0.87)$ & $7.15(1.12)$ & 0.103 & $<0.001$ \\
\hline & After intervention & $6.76(0.98)$ & $7.21(1.11)$ & 0.051 & \\
\hline & $P$-value & $<0.001$ & 0.657 & & \\
\hline \multirow[t]{3}{*}{ SIRT1 (ng/ml) } & Baseline & $24.94(4.38)$ & $25.57(3.37)$ & 0.455 & $<0.001$ \\
\hline & After intervention & $27.90(5.58)$ & $23.40(3.88)$ & $<0.001$ & \\
\hline & $P$-value & $<0.001$ & $<0.001$ & & \\
\hline \multirow[t]{3}{*}{ Irisin (ng/ml) } & Baseline & $18.15(5.96)$ & $20.13(7.17)$ & 0.171 & \\
\hline & After intervention & $21.99(5.93)$ & $14.98(2.76)$ & $<0.001$ & $<0.001$ \\
\hline & $P$-value ${ }^{* *}$ & $<0.001$ & $<0.001$ & & \\
\hline \multirow[t]{3}{*}{ HOMA-IR (N) } & Baseline & $5.36(3.23)$ & $5.83(3.09)$ & 0.499 & 0.421 \\
\hline & After intervention & $6.44(3.73)$ & $7.39(4.58)$ & 0.295 & \\
\hline & $P$-value & 0.006 & 0.003 & & \\
\hline \multirow[t]{3}{*}{ QUICKI (N) } & Baseline & $0.76(0.08)$ & $0.73(0.06)$ & 0.149 & 0.645 \\
\hline & After intervention & $0.73(0.07)$ & $0.71(0.07)$ & 0.217 & \\
\hline & $P$-value ${ }^{* *}$ & 0.005 & 0.003 & & \\
\hline
\end{tabular}

*Independent t-test, **Paired t-test, ${ }^{* * *}$ ANCOVA

smoking, alcohol intake history, and the lower dietary intake of fish. In addition, obesity and physical inactivity are important risk factors for T2D. However, in this trial, differences in physical activity levels were nonsignificant. Serum VD levels can be directly related to central adiposity [49] wasn't measured in our participants. Accordingly, the relationship between Vitamin D and glucose profiles can also be interpreted.

Vitamin D can increase insulin receptor gene expression in beta cells, glucose transport in the intestine [50], and intestinal calcium absorption may serve as stimuli for insulin release. In addition, some VDRs on beta cells can turn 25(OH)D3 (calcidiol) into the active VD $[51,52]$.

The more reasons for the differences between our trial and other studies may be unadjusted confounders, the different designs, the variety of dietary patterns, and the dose or timing of hyperglycemia medications.

This study has several strengths. First, the doubleblinded stratified blocked randomization design; Second, considering multiple eligibility criteria; Third, the determining of dietary intakes and physical activity status and adjusting the statistical analysis for them and other potential confounders; Fourth, considering control group. These strengths are likely preferable in comparison with the few other clinical trials that have evaluated the effects of VD in T2D.

However, our study had some limitations. First, the sample size was small; Second, the intervention duration was likely short to understand the real effects of VD supplementation on the different markers in T2D patients;

Table 6 The mean and standard deviation of the secondary variable before and after intervention in type 2 diabetes patients

\begin{tabular}{|c|c|c|c|c|c|}
\hline & & $\begin{array}{l}\text { Vitamin D } \\
(N=42)\end{array}$ & $\begin{array}{l}\text { Placebo } \\
(N=43)\end{array}$ & $P$-value & Adjusted $P$-value ${ }^{* * *}$ \\
\hline \multirow[t]{3}{*}{$\mathrm{FBS}(\mathrm{mg} / \mathrm{dl})$} & Baseline & $172.48(62.16)$ & $178.28(71.74)$ & 0.629 & 0.130 \\
\hline & After intervention & $175.52(65.44)$ & $162.72(61.36)$ & 0.355 & \\
\hline & $P$-value ${ }^{* *}$ & 0.742 & 0.053 & & \\
\hline \multirow[t]{3}{*}{ Insulin (miclU/ml) } & Baseline & $12.64(5.94)$ & $14.09(6.43)$ & 0.284 & 0.101 \\
\hline & After intervention & $15.31(7.24)$ & $18.77(9.02)$ & 0.055 & \\
\hline & $P$-value ${ }^{* *}$ & 0.002 & $<0.001$ & & \\
\hline
\end{tabular}

*Independent t-test, **Paired t-test, ***ANCOVA 
Third, disregarding non-obese patients. Fourth, selfreporting of diet and physical activity; Fifth, failure to measuring serum parathyroid hormone (PTH), Apolipoprotein $\mathrm{A} 1$, and the more sensitive inflammatory factors; Sixth, 24-h food recall is not a good index for assessing the usual food intake; Seventh, failure to measuring body composition. Even so, this study is the first trial of VD effects on serum SIRT1 and irisin levels in overweight/obese T2D patients.

We suggest similar trials measuring adipose tissue distribution and considering more potential confounders and the longer intervention period.

\section{Conclusion}

Vitamin D supplementation improves serum 25- $(\mathrm{OH})$ VD, SIRT1, irisin, and glycosylated hemoglobin in VD deficient T2D patients. The decrease of HbA1c may be related to the increased serum VD and irisin levels. Further trials are suggested.

\section{Supplementary information}

Supplementary information accompanies this paper at https://doi.org/10. 1186/s12875-020-1096-3.

Additional file 1: Table S1. The measurement tools and descriptions of companies.

\section{Abbreviations}

ANCOVA: Analysis of covariance; BMI: Body mass index; ELISA: Enzyme-linked immunosorbent assay; FBS: Fasting blood sugar; FGF21: Fibroblast Growth Factor 21; FOXO: Forkhead box O; HbA1c: Glycosylated hemoglobin; HOMAIR: Homeostasis model assessment-insulin resistance; hs-CRP: High-sensitivity C-Reactive Protein; IL-6: Interleukin 6; IMOS: Iranian Multi-Centric Osteoporosis Study; IPAQ: International physical activity questionnaire; IR: Insulin resistance; ITT: Intention to treat; NF-KB: Nuclear Factor kappa-light-chain-enhancer of activated B cells; PGC-1a: PPAR- $\gamma$ coactivator-1 alpha; PPAR: Peroxisome proliferation activated receptor; PPAR- $\gamma$ : Peroxisome Proliferation Activated Receptor-Gamma; QUICKI: Quantitative insulin sensitivity check index; SIRT1: Sirtuin-1; T2D: Type 2 diabetes; TNF-a: Tumour Necrosis Factor-Alpha; UCP1: Uncoupling Protein 1; VD: Vitamin D; VDR: Vitamin D receptor

\section{Acknowledgments}

The supports of Iran University of Medical Sciences and the cooperation of the Dr. Abrishami clinical laboratory, Bandar-E-Anzali, and all healthcare professionals and patients participated in the study are acknowledged.

\section{Consent fo publication}

Not applicable.

\section{Authors contributions}

PS and MV conceived and developed the idea for the paper and revised the manuscript. MN, MM, FM, FSA, and MDM contributed to data collection. PS and MDM wrote numerous drafts. $\mathrm{L}$ and HS contributed to statistical interpretations. All authors read and approved the final manuscript.

\section{Funding}

Funding (PhD grant) was supported by the Iran University of Medical Sciences (grant no. 1395.9223475201). The funding body did not have a role in the design of the study, collection, analysis, and interpretation of data, and writing the manuscript.

\section{Availability of data and materials}

The datasets used and/or analyzed during the current study are available from the corresponding author on a reasonable request.

\section{Ethics approval and consent to participate}

This trial was approved by the ethics committee of the Iran University of Medical Sciences (Ethical Code: IR.IUMS.REC.1395.9223475201). A written informed consent form (in Persian) obtained from all the patients. Participation was free, and a patient could withdraw at whatever point the person feels he/she was unable to continue. There was no bar for the patients to receiving the other health care services of the center. The personal information of patients was kept secret before, during, and after the study.

\section{Competing interests}

The authors declare that they have no competing interests.

\section{Author details}

${ }^{1}$ Department of Nutrition, School of Public Health, Iran University of Medical Sciences, Tehran, Iran. ²Department of Nutrition, School of Medicine, Jiroft University of Medical Sciences, Jiroft, Kerman, Iran. ${ }^{3}$ Department of Biochemistry, School of Medicine, Iran University of Medical Sciences, Tehran, Iran. ${ }^{4}$ Department of Biostatistics, School of Public Health, Preventive Medicine and Public Health Research Center, Iran University of Medical Sciences, Tehran, Iran. ${ }^{5}$ Department of Medicine, School of Medicine, Guilan University of Medical Sciences, Guilan, Iran. 'Department of Epidemiology, University of Massachusetts Lowell, Lowell, MA, USA.

Received: 5 November 2019 Accepted: 23 January 2020

Published online: 07 February 2020

\section{References}

1. Association AD. Diagnosis and classification of diabetes mellitus. Diabetes Care. 2004:27(suppl 1):s5-s10.

2. Himmetoglu S, Teksoz S, Zengin K, Yesim T, Taskın M, Dincer Y. Serum levels of fetuin a and 8-hydroxydeoxyguanosine in morbidly obese subjects. Exp Clin Endocrinol Diabetes. 2013;121(08):505-8.

3. Kimiagar M, Pourshams A, Majd SK, Goglani G, Jaafari E, Semnani S, et al. Vitamin deficiency in Golestan Province, northern Iran: a high-risk area for esophageal cancer. Arch Iran Med. 2010;13(5):391.

4. Heshmat R, Mohammad K, Majdzadeh S, Forouzanfar M, Bahrami A, Ranjbar Omrani G, Nabipour I, Rajabian R, Hossein-Nezhad A, Rezaei Hemami M, Keshtkar A, Pajouhi M. Vitamin D Deficiency in Iran: A Multi-center Study among Different Urban Areas. Iran J Public Health. 2008;37(sup):72-78. http://ijph.tums.ac.ir/index.php/ijph/article/view/2901.

5. Baz-Hecht M, Goldfine AB. The impact of vitamin D deficiency on diabetes and cardiovascular risk. Curr Opin Endocrinol Diabetes Obes. 2010;17(2):113-9.

6. Nimitphong H, Chanprasertyothin S, Jongjaroenprasert W, Ongphiphadhanakul B. The association between vitamin D status and circulating adiponectin independent of adiposity in subjects with abnormal glucose tolerance. Endocrine. 2009;36(2):205-10.

7. Roth CL, Elfers C, Kratz M, Hoofnagle AN. Vitamin D deficiency in obese children and its relationship to insulin resistance and adipokines. J Obes. 2011:2011:495101.

8. Forouhi NG, Luan JA, Cooper A, Boucher BJ, Wareham NJ. Baseline serum 25-hydroxy vitamin $D$ is predictive of future glycemic status and insulin resistance. Diabetes. 2008;57(10):2619-25.

9. Chiu KC, Chu A, Go VLW, Saad MF. Hypovitaminosis D is associated with insulin resistance and $\beta$ cell dysfunction. Am J Clin Nutr. 2004;79(5):820-5.

10. Alvarez JA, Ashraf A. Role of vitamin D in insulin secretion and insulin sensitivity for glucose homeostasis. Int J Endocrinol. 2010;2010:351385.

11. Mathieu C, Gysemans C, Giulietti A, Bouillon R. Vitamin D and diabetes. Diabetologia. 2005;48(7):1247-57.

12. Iyer A, Panchal S, Poudyal H, Brown L. Potential health benefits of Indian spices in the symptoms of the metabolic syndrome: a review; 2009.

13. Salminen A, Kaarniranta K, Kauppinen A. Crosstalk between oxidative stress and SIRT1: impact on the aging process. Int J Mol Sci. 2013;14(2):3834-59.

14. Guclu A, Erdur F, Turkmen K. The emerging role of sirtuin 1 in cellular metabolism, diabetes mellitus, diabetic kidney disease and hypertension. Exp Clin Endocrinol Diabetes. 2016;124(03):131-9. 
15. Chung S, Yao H, Caito S, Hwang J-W, Arunachalam G, Rahman I. Regulation of SIRT1 in cellular functions: role of polyphenols. Arch Biochem Biophys. 2010;501(1):79-90.

16. Mayoral R, Osborn O, McNelis J, Johnson AM, Izquierdo $\mathrm{CL}$, Chung $\mathrm{H}$, et al. Adipocyte SIRT1 knockout promotes PPARY activity, adipogenesis and insulin sensitivity in chronic-HFD and obesity. Mol Metab. 2015;4(5):378-91.

17. Polidoro L, Properzi G, Marampon F, Gravina G, Festuccia C, Di Cesare E, et al. Vitamin D protects human endothelial cells from $\mathrm{H} 2 \mathrm{O} 2$ oxidant injury through the Mek/Erk-Sirt1 axis activation. J Cardiovasc Transl Res. 2013;6(2):221-31.

18. Irving BA, Still CD, Argyropoulos G. Does IRISIN have a BRITE future as a therapeutic agent in humans? Curr Obes Rep. 2014;3(2):235-41.

19. Guilherme A, Virbasius JV, Puri V, Czech MP. Adipocyte dysfunctions linking obesity to insulin resistance and type 2 diabetes. Nat Rev Mol Cell Biol. 2008;9(5):367-77.

20. J-q C, Y-y H, Gusdon AM, Qu S. Irisin: a new molecular marker and target in metabolic disorder. Lipids Health Dis. 2015;14(1):2.

21. Zhang C, Ding Z, Lv G, Li J, Zhou P, Zhang J. Lower irisin level in patients with type 2 diabetes mellitus: a case-control study and meta-analysis. J Diabetes. 2016;8(1):56-62.

22. Binay Ç, Paketçi C, Güzel S, Samancı N. Serum Irisin and oxytocin levels as predictors of metabolic parameters in obese children. J Clin Res Pediatr Endocrinol. 2017;9(2):124

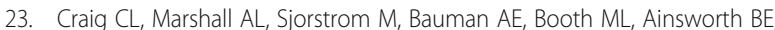
et al. International physical activity questionnaire: 12-country reliability and validity. Med Sci Sports Exerc. 2003;35(8):1381-95.

24. Nikooyeh B, Neyestani TR, Farvid M, Alavi-Majd H, Houshiarrad A, Kalayi A, et al. Daily consumption of vitamin D-or vitamin D+ calcium-fortified yogurt drink improved glycemic control in patients with type 2 diabetes: a randomized clinical trial. Am J Clin Nutr. 2011;93(4):764-71.

25. Matthews D, Hosker J, Rudenski A, Naylor B, Treacher D, Turner R. Homeostasis model assessment: insulin resistance and $\beta$-cell function from fasting plasma glucose and insulin concentrations in man. Diabetologia. 1985;28(7):412-9.

26. Katz A, Nambi SS, Mather K, Baron AD, Follmann DA, Sullivan G, et al. Quantitative insulin sensitivity check index: a simple, accurate method for assessing insulin sensitivity in humans. J Clin Endocrinol Metabol. 2000;85(7):2402-10.

27. Baziar N, Jafarian K, Shadman Z, Qorbani M, Nikoo MK, Mishani MA. Effect of therapeutic dose of vitamin $D$ on serum adiponectin and glycemia in vitamin D-insufficient or deficient type 2 diabetic patients. Iran Red Crescent Med J. 2014;16(9):e21458.

28. Joseph R, Sim J, Ogollah R, Lewis M. A systematic review finds variable use of the intention-to-treat principle in musculoskeletal randomized controlled trials with missing data. J Clin Epidemiol. 2015;68(1):15-24.

29. Holick MF, Binkley NC, Bischoff-Ferrari HA, Gordon CM, Hanley DA, Heaney RP, et al. Evaluation, treatment, and prevention of vitamin D deficiency: an Endocrine Society clinical practice guideline. J Clin Endocrinol Metabol. 2011;96(7):1911-30

30. Association WM, World Medical Association Declaration of Helsinki. Ethical principles for medical research involving human subjects. Bull World Health Organ. 2001;79(4):373.

31. Borissova A, Tankova T, Kirilov G, Dakovska L, Kovacheva R. The effect of vitamin D3 on insulin secretion and peripheral insulin sensitivity in type 2 diabetic patients. Int J Clin Pract. 2003;57(4):258-61.

32. Heshmat $R$, Tabatabaei-Malazy $O$, Abbaszadeh-Ahranjani S, Shahbazi $S$, Khooshehchin G, Bandarian F, et al. Effect of vitamin D on insulin resistance and anthropometric parameters in type 2 diabetes; a randomized doubleblind clinical trial. DARU J Pharmaceut Sci. 2012;20(1):10.

33. Nasri $H$, Behradmanesh $S$, Maghsoudi AR, Ahmadi A, Nasri P, Rafieian-Kopaei M. Efficacy of supplementary vitamin D on improvement of glycemic parameters in patients with type 2 diabetes mellitus; a randomized double blind clinical trial. J Renal Inj Prev. 2014;3(1):31.

34. Krul-Poel YH, Westra S, ten Boekel E, ter Wee MM, van Schoor NM, van Wijland $\mathrm{H}$, et al. Effect of vitamin D supplementation on glycemic control in patients with type 2 diabetes (SUNNY trial): a randomized placebocontrolled trial. Diabetes Care. 2015;38(8):1420-6.

35. Ryu O-H, Chung W, Lee S, Hong K-S, Choi M-G, Yoo HJ. The effect of highdose vitamin $\mathrm{D}$ supplementation on insulin resistance and arterial stiffness in patients with type 2 diabetes. Korean J Intern Med. 2014;29(5):620.

36. Taylor A, Wise P. Vitamin D replacement in Asians with diabetes may increase insulin resistance. Postgrad Med J. 1998;74(872):365-6.

37. Anastasilakis A, Polyzos S, Makras P, Gkiomisi A, Bisbinas I, Katsarou A, et al. Circulating irisin is associated with osteoporotic fractures in postmenopausal women with low bone mass but is not affected by either teriparatide or denosumab treatment for 3 months. Osteoporos Int. 2014; 25(5):1633-42

38. Cavalier É, Mismetti V, Souberbielle JC. Evaluation of circulating irisin levels in healthy young individuals after a single 100,000 IU vitamin D dose. InAnnales d'endocrinologie. 2014;75(3):162-164. Elsevier Masson. https:// www.sciencedirect.com/science/article/abs/pii/S0003426614000717.

39. Śliwicka E, Cisoń T, Kasprzak Z, Nowak A, Pilaczyńska-Szcześniak Ł. Serum irisin and myostatin levels after 2 weeks of high-altitude climbing. PLoS One. 2017;12(7):e0181259.

40. Al-Daghri N, Al-Attas O, Alokail M, Alkharfy K, Draz H, Clerici M. Serum 25hydroxy-vitamin $\mathrm{D}$ is associated with adiponectin and insulin resistance in diabetic Saudi adults; 2011.

41. Nielsen NO, Bjerregaard P, Rønn PF, Friis H, Andersen S, Melbye M, et al. Associations between vitamin $D$ status and type 2 diabetes measures among Inuit in Greenland may be affected by other factors. PLoS One. 2016;11(4):e0152763.

42. Eftekhari M, Akbarzadeh M, Dabbaghmanesh M, Hasanzadeh J. Effects of treatment with oral calcitriol on plasma glucose and insulin levels in noninsulin dependent diabetes mellitus patients. Iranian J Nutr Sc Food Technol. 2011;6(3):1-10.

43. Tabesh M, Azadbakht L, Faghihimani E, Tabesh M, Esmaillzadeh A. Effects of calcium-vitamin D co-supplementation on metabolic profiles in vitamin D insufficient people with type 2 diabetes: a randomised controlled clinical trial. Diabetologia. 2014;57(10):2038-47.

44. Rad EY, Djalali M, Koohdani F, Saboor-Yaraghi AA, Eshraghian MR, Javanbakht $\mathrm{MH}$, et al. The effects of vitamin D supplementation on glucose control and insulin resistance in patients with diabetes type 2: a randomized clinical trial study. Iran J Public Health. 2014;43(12):1651.

45. Al-Sofiani ME, Jammah A, Racz M, Khawaja RA, Hasanato R, El-Fawal HA, et al. Effect of vitamin D supplementation on glucose control and inflammatory response in type II diabetes: a double blind, randomized clinical trial. Int J Endocrinol Metab. 2015;13(1):e22604.

46. Sheth JJ, Shah A, Sheth FJ, Trivedi S, Lele M, Shah N, et al. Does vitamin D play a significant role in type 2 diabetes? BMC Endocr Disord. 2015;15(1):5

47. Zhang J, Ye J, Guo G, Lan Z, Li X, Pan Z, et al. Vitamin D status is negatively correlated with insulin resistance in Chinese type 2 diabetes. Int Endocrinol. 2016;2016:1794894.

48. Vilà L, Roca C, Elias I, Casellas A, Lage R, Franckhauser S, et al. AAV-mediated Sirt1 overexpression in skeletal muscle activates oxidative capacity but does not prevent insulin resistance. Mol Therapy—Methods Clin Dev. 2016;5:16072.

49. Buijsse B. Vitamin D for prevention of type 2 diabetes: a clouded forecast for the sunshine vitamin. Lancet Diab Endocrinol. 2015;3(1):5-6.

50. Maestro B, Campion J, Davila N, Calle C. Stimulation by 1, 25dihydroxyvitamin D3 of insulin receptor expression and insulin responsiveness for glucose transport in U-937 human promonocytic cells. Endocr J. 2000;47(4):383-91.

51. Pittas AG, Lau J, Hu FB, Dawson-Hughes B. The role of vitamin D and calcium in type 2 diabetes. A systematic review and meta-analysis. J Clin Endocrinol Metabol. 2007;92(6):2017-29.

52. Bland R, Markovic D, Hills CE, Hughes SV, Chan SL, Squires PE, et al. Expression of 25-hydroxyvitamin D 3-1a-hydroxylase in pancreatic islets. J Steroid Biochem Mol Biol. 2004;89:121-5.

\section{Publisher's Note}

Springer Nature remains neutral with regard to jurisdictional claims in published maps and institutional affiliations.

\section{Ready to submit your research? Choose BMC and benefit from:}

- fast, convenient online submission

- thorough peer review by experienced researchers in your field

- rapid publication on acceptance

- support for research data, including large and complex data types

- gold Open Access which fosters wider collaboration and increased citations

- maximum visibility for your research: over $100 \mathrm{M}$ website views per year

At $\mathrm{BMC}$, research is always in progress.

Learn more biomedcentral.com/submission 